\title{
Does cyclosporin A adversely affect Pneumocystis carinii infection?
}

\author{
R.J.S. McGonigle, M. Beaman, J. Stone, J. Young, J. Michael and D. Adu \\ Departments of Medicine and Pathology, Queen Elizabeth Hospital, Birmingham B15 2TH, UK.
}

\begin{abstract}
Summary: Fourteen immunosuppressed patients with Pneumocystis carinii infection presented in two clusters that were separated by 2 years. The diagnosis in all cases was made early by alveolar lavage with cytology. The first group of seven patients was immunosuppressed with cyclophosphamide or azathioprine and prednisolone. All recovered with high dose co-trimoxazole. The second group of seven patients was on prednisolone and cyclosporin A. Despite identical treatment three patients died and a further two who survived lost their grafts from rejection. Our data suggest that cyclosporin $A$ adversely affects the prognosis from Pneumocystis carinii infection and raises the question of prophylactic co-trimoxazole in these patients. The clustering of Pneumocystis carinii infection suggests the possibility of nosocomial transmission although in this study we were unable to implicate person-to-person spread of infection.
\end{abstract}

\section{Introduction}

Pneumocystis carinii is a well documented cause of atypical pneumonia in immunocompromised patients. The incidence of $P$. carinii has been reported to be less than $1 \%$ in renal transplant patients. ${ }^{1}$ More recently this incidence has been reported to be as high as $9 \%$ in renal transplant patients receiving cyclosporin $\mathrm{A}$ and prednisolone immunosuppression. ${ }^{2}$

The origin of $P$. carinii infection remains uncertain. It is generally accepted that most cases are due to re-activation of latent organisms present in patients' lungs. Reports of clusters or outbreaks make direct person-to-person or nosocomial transmission a distinct possibility although conclusive evidence for this is lacking. The present report describes a clustering phenomenon and a poor prognosis in patients receiving immunosuppression with cyclosporin A.

\section{Patients and methods}

Fourteen patients with Pneumocystis carinii pneumonia are described. Clinical details of patients are shown in Tables I and II. The first group of patients (Table I) was being treated with azathioprine $(2-2.5 \mathrm{mg} / \mathrm{kg} / \mathrm{day})$ or cyclophosphamide (2$3 \mathrm{mg} / \mathrm{kg} /$ day) adjusted according to the leucocyte count and the second group (Table II) received

Correspondence: R.J.S. McGonigle, M.R.C.P.

Accepted: 16 March 1988 cyclosporin A starting at $15 \mathrm{mg} / \mathrm{kg} /$ day orally and reduced to a maintenance dose to keep whole blood trough levels within the recommended therapeutie range. Both groups received prednisolone in similar dosage ranging from 10 to $20 \mathrm{mg}$ /day at the time the $P$. carinii infection was diagnosed. Prophylactic co-trimoxazole is not prescribed. The first group presented between June 1981 and July 1982, and there were no further episodes until the second cluster nearly 2 years later between May 1984 and September 1984. Two patients in Table I were on immunosuppressive therapy because of systemic lupus erythematosus; the remaining 12 patients were renal transplant recipients. Patients suspected of having opportunistic chest infections were investigated by fibre-optic bronchoscopy with segmental alveolar lavage. ${ }^{3}$ Treatment consisted of high dose intravenous co-trimoxazole (1920 mg 6-hourly) in all cases. In addition, two patients in Group 2 received pentamidine $200 \mathrm{mg}$ i.v. daily.

Microbiological examination of lavage samples included Gram, Ziehl-Nielsen and modified ZiehlNielsen staining. Wet preparations were examined for fungal hyphae. Culture for bacterial pathogens including Legionella and Mycobacteria were set up on all samples. In addition, virus isolation in tissue culture was attempted. We rapidly established a diagnosis in all 14 patients using cytology of alveolar fluid as previously described. ${ }^{3}$ Culture for Pneumocystis carinii in Vero and MRC 5 cells were performed on two specimens. ${ }^{4}$ Cytological examination included staining by Papanicolau, Ziehl- 
Table I Patients in Group 1 (no. 1-7) immunosuppressed with cyclophosphamide/azathioprine

\begin{tabular}{|c|c|c|c|c|c|c|}
\hline Patient & $\begin{array}{c}\text { Age } \\
\text { (years) }\end{array}$ & Sex & $\begin{array}{c}\text { Duration of } \\
\text { immunosuppressive } \\
\text { treatment (weeks) }\end{array}$ & $\begin{array}{c}\text { Temperature } \\
\text { on admission } \\
\left({ }^{\circ} \mathrm{C}\right)\end{array}$ & $\begin{array}{l}\text { Arterial } \\
\mathrm{PO}_{2} \\
\text { saturation } \\
(\mathrm{kPa})\end{array}$ & Outcome \\
\hline 1 & 29 & $\mathrm{~F}$ & 4 & $39^{6}$ & 5.7 & $\begin{array}{l}\text { Chronic renal failure } \\
\text { Not ventilated } \\
\text { on haemodialysis } \\
\text { Lived }\end{array}$ \\
\hline 2 & 24 & F & 4 & $37^{8}$ & 7.9 & $\begin{array}{l}\text { Chronic renal failure } \\
\text { Not ventilated } \\
\text { Lived }\end{array}$ \\
\hline 3 & 51 & $\mathbf{M}$ & 250 & $38^{7}$ & 4.5 & $\begin{array}{l}\text { Not ventilated } \\
\text { Lived } \\
\text { Stable graft function }\end{array}$ \\
\hline 4 & 26 & $\mathbf{M}$ & 300 & Apyrexial & 7.2 & $\begin{array}{l}\text { Ventilated } \\
\text { Lived } \\
\text { Stable graft function }\end{array}$ \\
\hline 5 & 38 & $\mathbf{M}$ & 54 & $38^{2}$ & 8.4 & $\begin{array}{l}\text { Not ventilated } \\
\text { Lived } \\
\text { Stable graft function }\end{array}$ \\
\hline 6 & 45 & $\mathbf{M}$ & 8 & $37^{6}$ & 8.6 & $\begin{array}{l}\text { Not ventilated } \\
\text { Lived } \\
\text { Stable graft function }\end{array}$ \\
\hline 7 & 43 & $\mathbf{M}$ & 16 & Apyrexial & 9.3 & $\begin{array}{l}\text { Not ventilated } \\
\text { Lived } \\
\text { Stable graft function }\end{array}$ \\
\hline
\end{tabular}

Patients 1 and 2 had systemic lupus erythematosus, the remainder were renal allograft recipients. All patients received high dose co-trimoxazole (1920 mg 6-hourly).

Table II Patients in Group 2 (no. 8-14) immunosuppressed with cyclosporin A

\begin{tabular}{|c|c|c|c|c|c|c|}
\hline Patient & $\begin{array}{c}\text { Age } \\
\text { (years) }\end{array}$ & Sex & $\begin{array}{l}\text { Duration of } \\
\text { immunosuppressive } \\
\text { treatment (weeks) }\end{array}$ & $\begin{array}{c}\text { Temperature } \\
\text { on admission } \\
\left({ }^{\circ} \mathrm{C}\right)\end{array}$ & $\begin{array}{l}\text { Arterial } \\
\mathrm{PO}_{2} \\
\text { saturation } \\
\quad(k \mathrm{~Pa})\end{array}$ & Outcome \\
\hline 8 & 50 & $\mathbf{M}$ & 11 & Apyrexial & 5.8 & $\begin{array}{l}\text { Ventilated } \\
\text { Died }\end{array}$ \\
\hline 9 & 54 & $\mathrm{~F}$ & 12 & Apyrexial & 5.6 & $\begin{array}{l}\text { Ventilated } \\
\text { Graft function lost } \\
\text { Lived }\end{array}$ \\
\hline 10 & 41 & $\mathrm{~F}$ & 11 & Apyrexial & 6.1 & $\begin{array}{l}\text { Ventilated } \\
\text { Died }\end{array}$ \\
\hline 11 & 47 & $\mathrm{~F}$ & 12 & $39^{7}$ & 6.2 & $\begin{array}{l}\text { Not ventilated } \\
\text { Normal graft function } \\
\text { Lived }\end{array}$ \\
\hline 12 & 53 & $\mathbf{M}$ & 18 & Apyrexial & 5.9 & $\begin{array}{l}\text { Ventilated } \\
\text { Died }\end{array}$ \\
\hline 13 & 55 & $\mathbf{M}$ & 8 & $38^{6}$ & 9.0 & $\begin{array}{l}\text { Not ventilated } \\
\text { Graft function lost } \\
\text { Lived }\end{array}$ \\
\hline 14 & 26 & $\mathbf{M}$ & 16 & 39 & 8.6 & $\begin{array}{l}\text { Not ventilated } \\
\text { Normal graft function } \\
\text { Lived }\end{array}$ \\
\hline
\end{tabular}

All patients were renal allograft recipients. All patients received high-dose intravenous co-trimoxazole (1920 mg 6-hourly). Patients 12 and 14 also received intravenous pentamidine (200 mg daily). 
Nielsen, May-Grunwald-Giemsa and Grocott methanamine silver (GMS) methods. Differences between groups were compared using the Wilcoxon's Rank Sum test.

\section{Results}

No complications were encountered in patients undergoing bronchoscopy under local anaesthetic. Most patients were investigated within 24 hours of clinical suspicion of the diagnosis being made. Those patients in whom there was a delay in arranging bronchoscopy were treated with high dose co-trimoxazole immediately after clinical diagnosis.

Patients, particularly those receiving cyclosporin A treatment, tended to follow a similar clinical course. The first presenting symptom was dyspnoea alone occurring over 3 to 14 days. On admission the chest X-ray was normal or showed non-specific bilateral radiographic shadowing in the lower lobes, confluent shadowing developed radiographically over the next few days. Hypoxia $\left(\mathrm{PO}_{2} 5.6-9.0 \mathrm{kPa}\right)$ was either present or developed soon after admission. In the second group only three patients were pyrexial and they all survived.

The two groups of patients each presented within a period of 12 months separated by 2 years. The mean age of the first group was lower $(36.5 \pm 10.4$ years) than the second ( $46.6 \pm 10.3$ years). However, this did not achieve statistical significance $(P>0.05)$. Renal allograft recipients in our renal unit may receive immunosuppressive treatment with either azathioprine or cyclosporin A but all seven infected transplant recipients in the second group were being treated with cyclosporin A. Despite a high index of suspicion and early clinical diagnosis cyclosporin A treated patients in the second group had a worse prognosis. In contrast to the first group in which all patients showed a complete recovery, four patients in the second group required assisted ventilation of whom three died with nonfunctioning renal grafts and two other patients lost graft function. Two patients in this second group received additional therapy with pentamidine i.v. $200 \mathrm{mg}$ daily; one patient died and the second patient recovered with normal renal function. Two patients developed severe leucopenia and thrombocytopaenia probably as a complication of cotrimoxazole. No patient in either group was receiving concomitant treatment with folinic acid.

\section{Discussion}

Pneumocystis carinii is an uncommon lung infection usually confined to immunocompromised sub- jects including renal transplant recipients. The mechanism of transmission of infection is unclear and attempts to prove transmission in outbreaks of the disease have been inconclusive. ${ }^{5}$ Serology indicates that most normal people have been infected with $P$. carinii during early childhood ${ }^{6}$ and that reactivation of latent organisms may occur, but this does not explain the clustering phenomenon. Airborne transmission has been shown in laboratory animals ${ }^{7}$ but has not been confirmed in humans.

The method of diagnosis of $P$. carinii infections in this hospital has not changed and both cyclosporin $\mathrm{A}$ and azathioprine have been used as immunosuppressive agents for renal transplantation in our unit over this period. Both cyclosporin $A$ and high dose steroids have been shown to induce $P$. carinii pneumonia in rats, ${ }^{8}$ and it has been suggested that cyclosporin A treatment increases the susceptibility to $P$. carinii infections in humans. $^{2}$

The emergence of strains of $P$. carinii resistant to co-trimoxazole might contribute to the different outcome between the two groups of patients. Most studies report a cure rate of approximately $80 \%$ using co-trimoxazole. ${ }^{9}$ Hardy et al. $^{2}$ showed an increased frequency of cytomegalovirus (CMV) infection in patients with $P$. carinii infection in comparison to controls which may indirectly indio cate decreased immune responsiveness, althougto CMV could be acting synergistically with $P$. carini $P$ It has even been suggested that $P$. carinii acts as a vector for CMV particles in some instances. ${ }^{10}$ Of the three patients who died one had evidence of CMV and a second had herpes simplex virus isolated from lavage material. No other risk factors could be identified except the need for mechanical ventilation, which reflects the severity of the lung lesion.

We still consider co-trimoxazole to be the treatment of choice in pneumocystis pneumonia. Therapeutic serum levels are more reliably obtained using the i.v. route and low serum sulphonamide and trimethoprim concentrations following oral administration have been reported. ${ }^{11}$ Chemoprophylaxis with co-trimoxazole has been shown to be effective. ${ }^{12}$ However, it is a bacteriostatic rather than a bacteriocidal drug against $P$. carinii $^{13}$ making the patient prone to infection once prophylaxis is stopped. ${ }^{14}$ There is also a theoretical risk of resistant strains emerging during prophylaxis and synergistic nephrotoxicity with cyclosporin $\mathrm{A}$ has been reported. The diagnosis of $P$. carinii infection is often difficult. We established a rapid diagnosis in all 14 patients using cytology of alveolar fluid. ${ }^{3}$ Clinical suspicion of $P$. carinii infection must be high even though the signs are variable. Classic radiographic abnormalities of diffuse infiltrates and alveolar shadowing are not a consistent finding in 
$P$. carinii infection. ${ }^{15}$ The severity of the disease could not be accurately assessed radiologically. Pyrexia was also an unreliable indicator of infection particularly in those patients receiving cyclosporin A. The only consistent finding was hypoxia $\left(\mathrm{PO}_{2}\right.$ $4.5-9.3 \mathrm{kPa}$ ) which was also found in the six patients reported by Ballardie et al. ${ }^{15}$ All six patients in their series recovered; however, none

\section{References}

1. Walzer, P.D., Perl, D.P., Krogstad, D.J., Rawson, P.E. \& Shultz, M.E. Pneumocystis carinii pneumonia in the United States. Ann Intern Med 1974, 80: 83-93.

2. Hardy, A.M., Wajszczuk, C.P., Suffredini, A.F., Hakala, T.R. \& Ho, M. Pneumocystis carinii pneumonia in renal transplant recipients treated with cyclosporine and steroids. $J$ Infect Dis 1984, 149: 143-147.

3. Hopkin, J.M., Young, J.A., Turney, J.H., Adu, D. \& Michael, J. Rapid diagnosis of obscure pneumonia in immunosuppressed renal patients by cytology of alveolar lavage fluid. Lancet 1983, ii: 299-301.

4. Latorre, C.R., Sulzer, A.J. \& Norman, L.G. Serial propagation of Pneumocystis carinii in cell line cultures. Appl Envir Microbiol 1977, 33: 1204-1206.

5. Burke, B. \& Good, R.A. Pneumocystis carinii infection. Medicine (Baltimore) 1973, 52: 23-51.

6. Pifer, L.L., Hughes, W.T., Stagno, S. \& Woods, D. Pneumocystis carinii infection - evidence for high prevalence in normal and immunosuppressed children. Pediatrics 1978, 61: 35-41.

7. Hughes, W.T. Natural mode of acquisition for de novo infection with Pneumocystis carinii. J Infect Dis 1982, 145: 842-848.

8. Hughes, W.T. \& Smith, B. Provocation of infection due to Pneumocystis carinii by cyclosporin A. J Infect Dis 1982, 145: 767. were currently using cyclosporin A for immunosuppression.

Our data suggest that cyclosporin A increases the incidence and adversely affects the prognosis of immunocompromised patients with $P$. carinii infection despite prompt diagnosis and treatment with high dose co-trimoxazole.

9. Young, L.S. Trimethoprim-sulfamethoxazole in the treatment of adults with pneumonia due to Pneumocystis carinii. Rev Infect Dis 1982, 4: 608-613.

10. Ernst, P., Chen, M.-F., Wang, M.-S. \& Cosio, M. Symbiosis of Pneumocystis carinii and cytomegalovirus in a case of fatal pneumonia. Can Med Ass J 1983, 128: 1089-1092.

11. Winston, D.J., Lau, W.K., Gale, R.P. \& Young, L.S. Trimethoprim-sulfamethoxazole for the treatment of Pneumocystis carinii pneumonia. Ann Intern Med 1980 , 92: 762-769.

12. Hughes, W.T. Five-year absence of Pneumocystis carinii pneumonitis in a paediatric oncology centre. $J$ Infect Dis 1984, 150: 305-306.

13. Pesanti, E.L. In vitro effects of antiprozoan drugs and immune serum on Pneumocystis carinii. J Infect Dis 1980, 141: 775-780.

14. Hughes, W.T. Limited effect of trimethoprimsulfamethoxazole prophylaxis on Pneumocystis carinii. Antimicrob Agents and Chemother 1979, 16: 333-335.

15. Ballardie, F.N., Winearls, C.E., Cohen, J.J., Carr, D.H., Rees, A.J. \& Williams, G. Pneumocystis carinii pneumonia in renal transplant recipients - clinical and radiographic features, diagnosis and complications of treatment. $Q J$ Med 1985, 57 (223): 729-747. 